\title{
Teaching Matters: How State and Local Policymakers Can Improve the Quality of Teachers and Teaching
}

Thomas B. Corcoran

University of Pennsylvania, tomc@gse.upenn.edu

Follow this and additional works at: https://repository.upenn.edu/cpre_policybriefs

Part of the Educational Methods Commons, Education Policy Commons, International and Comparative Education Commons, and the Teacher Education and Professional Development Commons

\section{Recommended Citation}

Corcoran, Thomas B.. (2007). Teaching Matters: How State and Local Policymakers Can Improve the Quality of Teachers and Teaching. CPRE Policy Briefs.

Retrieved from https://repository.upenn.edu/cpre_policybriefs/36

View on the CPRE website.

This paper is posted at ScholarlyCommons. https://repository.upenn.edu/cpre_policybriefs/36

For more information, please contact repository@pobox.upenn.edu. 


\title{
Teaching Matters: How State and Local Policymakers Can Improve the Quality of Teachers and Teaching
}

\author{
Abstract \\ A growing body of evidence confirms what common sense has suggested all along: The quality of \\ teaching in the public schools matters for how well students learn. An important corollary is that poor \\ children, minority children, and children from nonEnglish-speaking homes are even more dependent on \\ the quality of their teachers than are more affluent, English-speaking, White children. Pressures to improve \\ teacher quality stem mainly from state efforts to hold local schools accountable for student achievement \\ and from the requirements of the No Child Left Behind Act. \\ Policymakers want to know how to train, license, recruit, select, deploy, assign, develop, evaluate, retain, \\ and compensate teachers to produce a well-qualified teacher in every classroom and especially in the \\ classrooms that need them the most--those in urban, high-poverty, high-minority, low-performing schools \\ (Ferguson, 1991; Sanders \& Rivers, 1996; Sanders \& Horn, 1998; Darling-Hammond, 2000). \\ State policy counts as a salient force in shaping teacher quality, with influence in domains including \\ teacher-licensing standards, teacher-education policies, compensation and evaluation, induction, \\ professional development, and data policy and systems. These were key issues addressed by the \\ National Commission on Teaching and America's Future (NCTAF, 1997) and the Teaching Commission \\ (2004). \\ This issue of CPRE Policy Briefs summarizes the findings on issues related to teacher quality in the \\ chapter authored by Thomas B. Corcoran in the book, The State of Education Policy Research (Cohen, \\ Fuhrman, \& Mosher, Eds., in press). This report also draws on discussions that took place during a \\ Summer, 2006, policy briefing on teacher labor-market issues held in Chicago and sponsored by the \\ Spencer Foundation.

\section{Disciplines} \\ Educational Methods | Education Policy | International and Comparative Education | Teacher Education \\ and Professional Development
}

\section{Comments}

View on the CPRE website. 


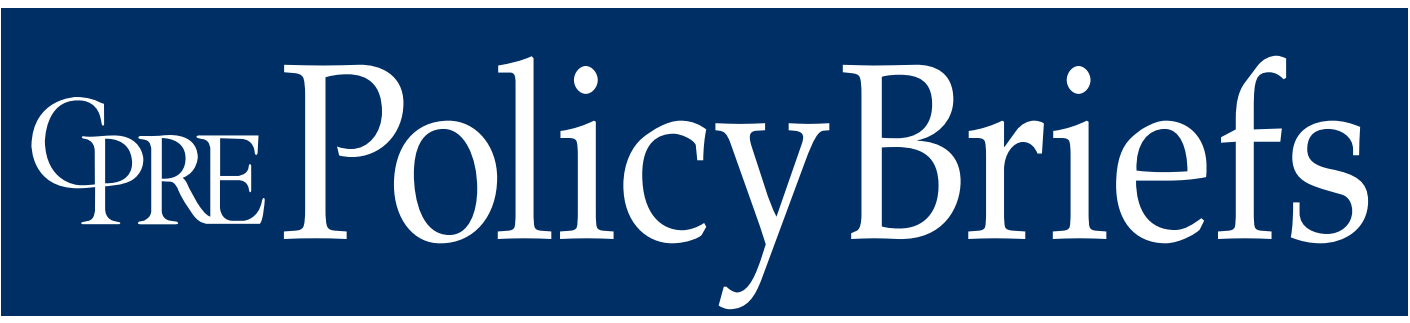

Reporting on Issues and Research in Education Policy and Finance
Teaching Matters: How State and Local Policymakers Can Improve the Quality of Teachers and Teaching

\author{
By Thomas B. Corcoran
}

\section{Introduction}

A growing body of evidence confirms what common sense has suggested all along: The quality of teaching in the public schools matters for how well students learn. An important corollary is that poor children, minority children, and children from nonEnglish-speaking homes are even more dependent on the quality of their teachers than are more affluent, English-speaking, White children. Pressures to improve teacher quality stem mainly from state efforts to hold local schools accountable for student achievement and from the requirements of the No Child Left Behind Act.

Policymakers want to know how to train, license, recruit, select, deploy, assign, develop, evaluate, retain, and compensate teachers to produce a well-qualified teacher in every classroom and especially in the classrooms that need them the most-those in urban, high-poverty, high-minority, low-performing schools (Ferguson, 1991; Sanders \& Rivers, 1996; Sanders \& Horn, 1998; Darling-Hammond, 2000).

State policy counts as a salient force in shaping teacher quality, with influence in domains including teacher-licensing standards, teacher-education policies, compensation and evaluation, induction, professional development, and data policy and systems. These were key issues addressed by the National Commission on Teaching and America's Future (NCTAF, 1997) and the Teaching Commission (2004).

This issue of CPRE Policy Briefs summarizes the findings on issues related to teacher quality in the chapter authored by Thomas B. Corcoran in the book, The State of Education
Policy Research (Cohen, Fuhrman, \& Mosher, Eds., in press). This report also draws on discussions that took place during a Summer, 2006, policy briefing on teacher labor-market issues held in Chicago and sponsored by the Spencer Foundation.

The backdrop for this review is a continuing and sometimes contentious debate over teacher quality. The "professionalism" viewpoint is that teaching is work that requires significant preparation and support and rigorous licensing standards (Cochran-Smith \& Fries, 2001; Fenstermacher, 2002). That view holds all teachers should have the content knowledge, teaching skills, and cultural understanding to serve all students well. Supporters of professionalism expect a teacher to know curriculum, learning theory and assessment, to have technical skills, and to understand school and community cultures (Oakes et al., 2002). The "deregulationist" view maintains that teaching is a task that most intelligent individuals can do, that the demands of teacher licensing are unnecessary and costly, that the skills required can be learned on the job, and that alternative routes into the profession can expand the pool of potential teachers.

\section{Licensing and Alternative Routes}

The states determine the qualifications individuals must possess to obtain licenses to work as teachers in public schools in their jurisdictions. In the past decade, testing has gained in popularity, and in 2005, 48 states required teachers to pass one or more tests to obtain a teaching license (Goldhaber, 2006). Most of the states use a test developed by the Educational Testing Service (ETS), but set different standards - cut scores-for passing.
February 2007 RB-48

Graduate School

of Education

University of

Pennsylvania

\section{Consortium for Policy Research in Education}

University

of Pennsylvania

Teachers College, Columbia University

Harvard University

Stanford University

University

of Michigan

University of

Wisconsin-Madison

Northwestern

University 
The American Board for Certification of Teacher Excellence (ABCTE) is developing a national test battery that would provide a common standard for states that adopted it, and a more portable license for teachers-again, in the states that adopted it.

How important is licensing? The best argument for licensing seems to be that it protects the public from poor local hiring decisions, but by itself licensing does not guarantee a high-quality teaching force (Evertson, et al., 1985; Darling-Hammond, 2000; Goldhaber \& Brewer, 2000). However, the research evidence is mostly weak; the debate between the regulationists and the free-market advocates about the value of licensing cannot be resolved anytime soon by appeals to research evidence.

Raising standards for entering teaching is an expensive proposition because of its implications for preparation programs, its effects on the candidate pool and the implications for recruitment, and the likelihood that more complex, costly assessments would be needed. The available evidence certainly justifies some experiments with new licensing policies-including policies that focus on individual competence — but does not justify making system-wide or large-scale change or making large investments in new licensing procedures. Policymakers would be well advised to stick with the systems they have in place until we have better evidence of the consequences of raising or eliminating standards and about who suffers those consequences. Clearly, well-designed experiments with different licensing regimes would help state policymakers decide which direction to take.

The evidence about the effectiveness of alternative routes to certification shows wide variability. Two recent reviews of the research concluded that alternative routes had been successful in recruiting a more diverse pool of teachers, but had a mixed record in terms of the quality of the teachers supplied. Also the data show some alternative-route programs are as effective as more traditional campusbased programs, and that the more effective alternative-route programs share common characteristics (Wilson, Floden, \& FerriniMundi, 2001). Several analysts have noted that there is more variation within, rather than between, traditional and alternative pathways into teaching. Research evidence also shows traditionally prepared teachers produce higher
The research reported in this brief was conducted by the Consortium for Policy Research in Education (CPRE) and funded by the Institute of Education Sciences, United States Department of Education, under Grant No. R308A960003. Opinions expressed in this Brief are those of the authors and do not necessarily reflect the views of the Institute of Education Sciences, the United States Department of Education, CPRE, or its institutional members.

student-achievement gains initially but that alternative-route recruits (among those still teaching) catch up by year three (Wyckoff et al., 2006). However, there is another consideration: a higher than typical attrition rate for alternative-certification teachers can leave students with a series of novice, untrained teachers (Wyckoff et al., 2006; Berry, 2005; Darling-Hammond, 2000).

The broad question about the effectiveness of alternate routes may not be worth asking given the growing variation in types of alternative routes and whom they serve (Allen, 2003). Feistritzer's annual reports of statistics (2006) about alternate pathways identify 10 different types. Research that examines the experience and performance of similar groups and the qualities of effective programs would prove more useful. Better evidence may be available in the near future.

\section{Teacher Education Policies}

The states do not have coherent policies on teacher education. There is enormous variation in the pathways students pursue to achieve certification and employment as teachers, and there is great variation among and within "traditional" training programs in terms of their visions of good teaching, standards for admission, rigor and amount of subject-matter preparation, clinical experiences provided, and quality of assessments. Moreover, the trainers of teachers have been slow to embrace evidence-based practice though some exemplary programs can be found. The resulting mishmash is the product of the interaction of state policy, collegiate institutional autonomy, the academic freedom claimed by the faculties who prepare teachers, and the layers of reforms that have accumulated.

There is growing disagreement about the best way to prepare teachers. Some argue that 
easing entry into teaching by eliminating requirements is the best way to attract strong candidates (U.S. Department of Education, 2002); others say that investing in the development of higher-quality teacher preparation programs will better serve children (National Commission on Teaching and America's Future, 1997). This group seeks to strengthen the role of arts and science faculty in teacher training, strengthen requirements for disciplinary study, expand clinical experiences for pre-service teachers, and build stronger internal accountability for teacher-education programs by examining the performance of their graduates. Teachers for a New Era (TNE), a foundation-funded initiative to design programs based on those principles, is under way in 11 universities (Carnegie Corporation of New York, 2001).

Every state except Arizona requires some form of state approval for teacher-preparation programs (Allen, 2003), and the trend has been toward adoption of national accreditation standards and processes. There are two national organizations that accredit teacher education programs - the National Council for the Accreditation of Teacher Education (NCATE) and a newer rival, the Teacher Education Accreditation Council (TEAC). Both are pressuring institutions to collect data on the performance of their graduates and to develop internal accountability systems - and norms - to help them improve. Both NCATE and TEAC are modeled after how other professions (medicine, architecture, etc.) enact quality control over university-based preparatory schools. More than 700 of the 1,200 universities preparing teachers are part of the NCATE system and 47 states are in partnership using NCATE standards to drive changes in how teachers are prepared.

There appears to be general agreement that the knowledge base underlying teacher education is weak. Three major reviews of research on teacher education (Allen, 2003; CochranSmith \& Zeichner, 2005; Wilson, Floden, \& Ferrini-Mundy, 2001) report only a small amount of high-quality research in key areas including how much or what kind of subjectmatter preparation is needed, what pedagogical skills are critical, how much clinical experience is needed, and the effects of state program approval and national accreditation.
The Teaching Commission (2006) has called for states and institutions to assess the results of teacher-education programs and to act on those results to improve, or close, ineffectual programs. The new national Data Quality Consortium formed by education organizations is encouraging the development of comprehensive data systems linking teachers and students to support value-added studies, and the U.S. Department of Education is investing in their development. But for now, the research literature on teacher education and accreditation of teacher-education programs provides only limited guidance for policymakers.

\section{Teacher Induction}

The NCTAF and the Teaching Commission both have strongly recommended that all states develop and adequately fund beginningteacher support programs. Well-designed supports are intended to provide novice teachers with support and guidance to facilitate a successful transition into the classroom, thereby increasing teacher retention and building a solid foundation for the development of teaching competence and professionalism. Within this framework, these programs typically provide personal support and professional guidance from a mentor, additional skills training, regular feedback on performance, and a summative assessment that may be connected to licensing. States have been experimenting with induction programs since the 1970s. While only eight states reported having induction programs in 1984, the number had increased to 31 by the early 1990s, and nearly two thirds of states required some kind of teacher induction programs by the end of the decade (Weiss \& Weiss, 1999).

Induction programs face multiple issues include finding and training sufficient numbers of accomplished teachers to serve as mentors, preparing principals and other administrators to accept and utilize mentors as teacher leaders for instruction, and aligning new teacher induction support with other district-level professional-development efforts (New Teacher Center at the University of California-Santa Cruz). Another topic for consideration is the emerging cost of teacher turnover and its implications for how much could be saved if high quality programs were funded and supported. A Texas study found that the state's annual $15.5 \%$ teacher turnover 
rate $(40 \%$ for new teachers within their first three years) costs the state a minimum of $\$ 330$ million per year. Related are the specific costs of high-quality programs, estimated at a minimum of $\$ 5,000$ per new teacher.

Teacher induction programs have distinct advantages over other initiatives aimed at the retention of teachers, such as increased salaries and loan forgiveness. In essence, they help teachers improve their teaching, in terms of pedagogical knowledge, teaching style, and overall knowledge of the core curriculum. Specific features of induction programs include new teacher workshops; formal assignment of a mentor and preparation for mentors; the use of case studies and videos; journal writing; ongoing assessment; participation in team-teaching situations; and providing a support team or a network of both new and experienced teachers with whom to share concerns and discuss issues (Torres, et al., 2004).

The most rigorous and complete reviews of teacher induction programs have been conducted by SRI International (2004), the EPPICentre (2004), and Ingersoll and Kralick (2004); all describe the research on induction and mentoring as weak. Ingersoll and Smith (2004) used data from the 1999-2000 Schools and Staffing Survey (SASS) and the 2000-2001 Teacher Follow-Up Survey to examine the effects of teacher participation in induction or mentoring programs. From the analysis of these data, they concluded that teacher induction programs were effective in reducing attrition among new teachers. The SASS data from 1990-1991, 1993-1994, and 1999-2000 show that the number of new teachers receiving support through induction has almost doubled in a 10-year period (Ingersoll \& Smith, 2004). After controlling for confounding factors like the background characteristics of the teachers and schools, Ingersoll and Smith found that teachers who receive intensive support - a mentor from the same field, common planning time with other teachers in the same subject, regularly scheduled collaboration with other teachers, membership in an external network of teachers-were less likely to leave the profession.

Ingersoll and Smith (2004) found that, among teachers who entered the profession in the 1999-2000 school year, 16\% received no induction supports, and they had a $40 \%$ probability of attrition by the end of their first year.
Teachers who received six various kinds of induction supports represented only $13 \%$ of the sample, and they had a turnover probability of $24 \%$.

One possible solution that also would contribute to the improvement of teacher education would be to encourage collaboration between school districts and higher education and utilize the resources of both institutions. Other promising strategies are to make more use of Web-based services and retired teachers to support beginning teachers.

\section{Professional Development}

Professional development for teachers in the United States is primarily funded, designed and delivered by local school districts. The menu of professional development for teachers consists primarily of three sets of activities: (1) formal supervision, (2) in-service training, and (3) collegial learning. States could play leadership roles in building effective professional-development systems we need by changing teacher recertification requirements; by demanding that regional or intermediate units deliver professional development that meets the consensus standards; and by providing guidance for local professional-development activities. Ten states had set quality standards for professional development by 2000 , but only a few states were using these standards to review local plans or state programs. Several states-Kentucky, Massachusetts, Michigan, and New Jerseyhad attempted to review the quality of providers of professional development to provide better information to the districts and schools that used their services. Still, all in all, the state role in shaping and improving professional development remained weak.

Nationwide or even statewide data on expenditures is lacking, but a set of welldesigned studies in large urban districts found that professional-development expenditures ranged from $2.2 \%$ to $6.9 \%$ of the operating budgets (Miles, et al., 2004). These estimates are somewhat higher than results reported in previous studies that ranged from $2 \%$ to $4 \%$ of operating budgets. This may be because urban districts have greater needs or more funds targeted at professional development, or because the studies in urban districts were based on a more carefully defined cost structure. 
Table 1. Features of Effective Professional Development

\section{Elements of Effective Teacher Development}

- A clear focus on the improvement of student learning in a specific content area and in a specific setting. Effective professional development is designed to help teachers meet the needs of real students in real classrooms.

- The form of the activity - that is, whether the activity is organized as a summer institute, university course, study group, teacher network, or mentoring collaborative. Research suggests that effective professional development often combines intensive off-site learning experiences with school-based and job-embedded opportunities to learn.

- The duration of the activity, that is, whether the activity is organized as a summer institute, university course, study group, teacher network, or mentoring collaborative. Research suggests that effective professional development often combines intensive off-site learning experiences with school-based and jobembedded opportunities to learn.

- The degree to which the activity emphasizes the collective participation of groups of teachers from the same school, department, or grade level and contributes to the development of their collaborative practice. Research suggests that the most effective professional development is organized around groups of teachers from a school who share responsibility for the same children and/or subject.

- The degree to which the activity is content-based-improving and deepening teachers' knowledge of the content of the curriculum they teach. Research concludes that teachers need to know well the content they teach, need to know common student miscues or problems students typically have learning that content, and need to know effective instructional strategies linking the two.

- An emphasis on active learning, as suggested by research on adult learning. Teachers are engaged in the meaningful analysis of teaching and learning, for example by scoring student work or developing and "perfecting" a standards-based curriculum unit or by observing a lesson and reflecting on it.

- The use of evidence in design. Evidence of the strengths and needs of learners in the setting and evidence of what works drawn from research and clinical experience enhances the likelihood that the professional development will contribute to better learning outcomes. It is important to provide teachers with models of effective practice, but even more important to improve their skills as diagnosticians and developers and users of knowledge about their practice.

- The creation of coherence by helping teachers see connections among student content and performance standards, instructional materials, local and state assessments, school and district goals, and the development of a professional community. Research supports tying professional development to a comprehensive, interrelated change process focused on improving student learning.

- The active support of school and district leaders. School leaders participate in these activities as appropriate in order to be able to support the use of the new knowledge and skills by teachers. 
A number of organizations (and some states) have developed standards of quality for professional development (Hawley \& Valli, 1999; National Commission on Teaching and America's Future, 1996; National Staff Development Council, 2001; American Federation of Teachers, 1999; Knapp, McCaffrey, \& Swanson, 2003). A good summary of this emerging consensus was produced by Elmore (2002), who compiled a set of principles for the design of effective professional-development programs.

The consensus view is that job-embedded professional development that is led by, designed by, and provided by teachers is the best model. But the research findings seem to suggest a slightly different vision-intensive, extended, curriculum-based training that is usually provided outside the workplace combined with on-site, job-embedded implementation support (Cohen \& Hill, 1998; Corcoran, McVay, \& Riordan, 2003; Elmore \& Burney, 1997; Garet, et al., 1999; Kennedy, 1999; Miller, Lord, \& Dorney, 1994; Supovitz, Mayer, \& Kahle, 2000; and Wilson \& Berne, 1999).

Effective professional development is that which produces the desired changes in teachers' classroom practices and enhances their capacity for continued learning and professional growth, which in turn contribute to improvements in student learning. There are a number of studies that have linked program strategies to changes in teachers' instructional practice, and sometimes but less frequently to gains in student achievement. However, the amount of research evidence linking these professional development principles to student learning is small at this point, so the principles listed in Table 1 are based on a combination of professional judgment and research.

Proponents have experienced enormous difficulties persuading either state or local policymakers to adopt effective strategies or make the necessary investments. Part of the problem is that there are so many small providers who lack the capacity to create solid programs but who benefit from the tendency of local decision-makers to follow fads. There also are large membership organizations with vested interests in particular approaches to professional development that make claims to being research-based but instead are driven by ideology or the interests of their members. So, we have "national" standards being promoted that are not wholly consistent with the research findings.

State policymakers should heed the importance of professional development, consider the amount of money that is being spent, and take action to improve the quality of what is provided for teachers, either by providing high-quality options as the California Subject Matter Projects did, or by enforcing standards and monitoring district and school expenditures.

\section{Teacher Compensation and Evaluation}

Prior to the 1990s, most efforts to move away from the single-salary schedule for teachers experimented with merit pay (Hatry, Greiner, \& Ashford, 1994; Murnane \& Cohen, 1986) or career-ladder programs (Freiberg \& Knight, 1991; Schlechty, 1989), very few of which worked or lasted. Strategies now are more varied and include signing bonuses; housing supplements; higher pay levels for teachers in shortage areas such as mathematics, science, and technology, or for teachers in hard-to-staff or low-performing schools; salary incentives for teachers who earn certification from the National Board for Professional Teaching Standards (NBPTS); more elaborate knowledge- and skill-based pay incentives (Milanowski, 2003); as well as school-based performance-award programs that provide cash bonuses to everyone in a school for improved student performance.

In terms of base pay, research is quite clear that neither education units, degrees nor years of experience (after the first three to five years) - the elements of the single- salary schedule-are linked to student-learning gains. Milanowski, Kimball, and Odden (2005) conclude that the new forms of standards- or performance-based teacher-evaluation systems are sufficiently reliable and valid to use in redesigned teacher-salary structures that would link higher pay levels to greater levels of teacher effectiveness in producing student learning gains, although these authors agree that there is still need for research on the operation and overall impact of such new structures.

Reforms in how teachers are paid-in particular, basing pay in part on some measure of performance-are gaining political traction. 
The Education Commission of the States (Azordegan, et al., 2005) reports that 20 governors identified teacher compensation as a major education issue in their 2005 state-ofthe-state addresses, and nine specifically mentioned merit pay. Some states have encouraged experimentation with compensation reforms. Kentucky and others have tried school-level performance rewards. Colorado, Kentucky, and Minnesota have used inducements to stimulate local experiments with performance-based pay. A number have provided salary increases for teachers achieving NBPTS certification. Quite a few districts use modest versions of the career ladder design"modest" because they are not perceived as threats to the single- salary schedule, either because the stipends are small or small numbers of teacher are affected, or both. Only a handful of districts have successfully implemented pay-for- performance designs.

Leaders of national and local teacher unions seem committed to the defense of the single-salary schedule despite evidence of unequal assignments (Corcoran, Walker, \& White, 1988) and systematic scarcities in specific teaching fields. States and districts have offered signing bonuses, loan forgiveness, assistance with housing, reimbursement of moving expenses, and tuition reimbursement to attract teachers in hard-to-fill positions in mathematics, science, bilingual education, and special education, but they have not touched the uniform salary schedule.

For policymakers, the issue will be to identify value-added models devoid of the measurement errors that can work to undermine the reform effort. So, experiments need to be tried and monitored, recognizing that knowledge- and skill-based pay systems are dependent on the creation of reliable, valid, and legitimated local evaluation systems. One issue to grapple with will be whether evaluation results will be kept private. Even where local administrators want to protect teachers and use data to help them improve, there is a risk that results will become public, leading to conflicts with parents and pressure to deal harshly with some teachers. Indeed, in some jurisdictions the media have indicated they would use freedom-of-information provisions to obtain the results of value-added analysis. Policymakers also should expect opposition from teachers' unions, as those associations have done in the past, although there have been some interesting exceptions. The resulting conflicts with administrators and policymakers have the potential of engendering long-term costs that might offset any productivity gains. In many states, it should be noted, salary schedules are determined locally, and neither local policymakers nor local teachers' unions are likely to welcome interference from the state.

Group- or school-based performance awards offer greater appeal to some by explicitly encouraging the collaborative nature of teaching, though advocates note that individual-based awards may indirectly encourage collaboration, as the awards are available to all teachers and thus not zero-sum systems (Solmon \& Podgursky, 2000). Further, groupbased awards may encourage teachers to address broader goals that match community and school expectations (Firestone, 1994; Kelley, Heneman, \& Milanowski, 2000). Studies generally find that teachers working in systems providing group rewards for performance exhibit greater motivation towards improved student performance, with motivation varying based on the teachers' perception of the award system's fairness (Heneman \& Milanowski, 1999; Kelley, Heneman, \& Milanowski, 2000).

Advocates for individual-based awards argue that when carefully incorporated into a sophisticated model of teacher quality, gains on student achievement tests can provide an independent measure for teacher performance, and can be included as one part of a teacher's evaluation (Solmon \& Podgursky, 2000). Similar to skill-based pay systems, performance systems focusing on individuals appear to have positive effects on the retention of highly qualified teachers, but no clear effects on teacher recruitment (Reichardt \& Van Buhler, 2003).

In light of the limited evidence, larger (perhaps regional) experiments with the Teaching Commission's recommendations to raise base pay, provide new advancement pathways, and pay extra for assignments to hard-to-staff schools seem in order. These experiments would have to be conducted in a large geographic area, a regional labor market, for example, in order to avoid simply encouraging teachers to move across district lines and shift the location of the labor problems. 


\section{State Data Policy and Data Systems}

For state policymakers to test alternative pathways to licensure, improve teacher education and professional development, make cost-effective investments in teacher induction, and test reforms in compensation, they will need access to better data on teachers and teaching. If they want to know how many candidates pursue different pathways to licenses, the characteristics of those candidates, how they perform on licensing exams, where they are employed, how long they stay in teaching, and how effective they are, they will need to invest in better data systems. If they are interested in which higher education institutions or which programs produce candidate qualified in particular fields, where the teaching vacancies are, how professional development funds are being spent, and answers to dozens of similar questions, they will need to create better data systems.

Most states have little data on teachers besides their licensing scores and their credentials. And most cannot link even these limited data about teachers to data on the students whom they teach, so researchers cannot conduct value-added studies to inform legislators, teacher training programs, and school districts. And in some of the states where such links can be made, they are not, because of concerns about harming teachers or being forced to release the data to the public. Only Florida, North Carolina, Tennessee, and Texas have the data elements needed to longitudinally link students and teachers; and only these states have begun to build the comprehensive, integrated databases needed to answer the critical questions facing policymakers (Berry, 2005). Without access to better indicators and better data systems, policymakers are not likely to improve the quality of teachers and teaching, as they lack the information needed to define problems correctly or evaluate the effectiveness of the policy options available to them.

Since the late 1970s, the states have been building databases on students to support their school accountability systems and provide comparable data on student, school, and district performance to policymakers and the public, but only recently has there been much interest in data on teachers. The Higher Edu- cation Act requires states to rank teacherpreparation programs in quartiles based on the performance of their graduates on state licensing tests. Some states such as Georgia, Kentucky, New York, and Texas have linked program approval to pass rates on these tests. However, state student achievement cannot be used as a measure of the effectiveness of teacher preparation programs, because no state has a system that seamlessly links teachers with the assessment results of their students and also with information on where and how they were prepared.

NCLB requires the states to ensure that students are taught by "highly qualified" teachers. A 2003 U.S. General Accounting Office report concluded that the states do not have the data systems needed to track teacher qualifications for the subjects they are teaching. Most states have to rely on districts to report on the qualifications of their staffs. The states are using different definitions as well as different methods of determining whether teachers are qualified, so their data are not comparable. In 2005, Alabama and Tennessee reported that approximately one third of classes were taught by highly qualified teachers, whereas Georgia and North Carolina claimed about $90 \%$ (U.S. Department of Education, 2005). These discrepancies are at least partly due to differences in state definitions, measurements, reporting processes, and data checking and cleaning procedures. Cross-state comparisons are not meaningful given the quality of the data available and the lack of common definitions and data collection procedures.

With NCLB as a stimulus, state policymakers are beginning to address these data system problems. To assist them, the federal government has initiated a grants program to support the design and development of new comprehensive state data systems. Grants were awarded in 2005 to 14 states to begin this work. Second, TNE is reaching out to policymakers in the 10 states in which it has awarded grants to institutions of higher education for the purpose of redesigning their teacher education programs. These institutions need access to teacher data systems that allow them to track their graduates, as Carnegie is asking these institutions to use evidence, particularly evidence of student learning, to examine the effectiveness of their graduates and improve 
Table 2. Teacher Labor Market Problems by Policy Level

\begin{tabular}{|l|l|l|l|}
\hline & \multicolumn{3}{|c|}{ Example Barriers by Policy Level } \\
\hline Labor Market Feature & National & State & District \\
\hline $\begin{array}{l}\text { Attracting people with } \\
\text { math/science/tech skills to } \\
\text { teaching }\end{array}$ & $\begin{array}{l}\text { Traditional occupational } \\
\text { pay differentials }\end{array}$ & $\begin{array}{l}\text { Lengthy certification } \\
\text { programs that require } \\
\text { extra forgone income }\end{array}$ & $\begin{array}{l}\text { Working conditions that } \\
\text { may turn off people with } \\
\text { these skills }\end{array}$ \\
\hline $\begin{array}{l}\text { Difficulty utilizing alter- } \\
\text { native sources of supply }\end{array}$ & $\begin{array}{l}\text { NCLB highly qualified } \\
\text { teacher provisions }\end{array}$ & $\begin{array}{l}\text { Rigid certification pro- } \\
\text { grams }\end{array}$ & $\begin{array}{l}\text { Undifferentiated job } \\
\text { design; limited district } \\
\text { HR capacity }\end{array}$ \\
\hline $\begin{array}{l}\text { Attracting and retaining } \\
\text { teachers in high-need } \\
\text { schools }\end{array}$ & $\begin{array}{l}\text { School finance systems } \\
\text { not adequacy based }\end{array}$ & $\begin{array}{l}\text { Rigid pay schedules, } \\
\text { poor working conditions }\end{array}$ \\
\hline $\begin{array}{l}\text { Redesigning teaching } \\
\text { work and school struc- } \\
\text { tures to allow higher pay } \\
\text { conception of one } \\
\text { teacher for each class }\end{array}$ & $\begin{array}{l}\text { Undifferentiated teacher } \\
\text { licensing systems }\end{array}$ & $\begin{array}{l}\text { Undifferentiated job } \\
\text { design; rigid teacher } \\
\text { contracts; limited district } \\
\text { HR capacity }\end{array}$ \\
\hline $\begin{array}{l}\text { Narrow geographical } \\
\text { scope of labor marke }\end{array}$ & $\begin{array}{l}\text { Old-fashioned societal } \\
\text { preparation and certifica- } \\
\text { tion systems }\end{array}$ & $\begin{array}{l}\text { District inability or } \\
\text { reluctance to recruit } \\
\text { nationally or provide } \\
\text { relocation incentives }\end{array}$ \\
\hline $\begin{array}{l}\text { Inability to adapt compen- } \\
\text { sation systems to district } \\
\text { and school needs }\end{array}$ & $\begin{array}{l}\text { Inefficient allocation of } \\
\text { compensation costs } \\
\text { between pay and benefits }\end{array}$ & $\begin{array}{l}\text { State-required benefit } \\
\text { plans }\end{array}$ & $\begin{array}{l}\text { Limited district HR } \\
\text { capacity }\end{array}$ \\
\hline
\end{tabular}

Source: Odden, Milanowski, \& Heneman, 2007. 
their programs. CPRE has conducted reviews of teacher policy in these states and discovered that the quality of state data systems, the lack of links between teacher and student databases, and problems gaining access to these data are major barriers to the TNE institutions in all 10 states (Corcoran et al., 2006). At present, these institutions are unable to track their graduates, even those teaching locally, let alone those who go to a different state or do not enter the profession. Without this information, the institutions cannot judge the success of their programs, and cannot set priorities for improvement. State policymakers face the same dilemma on a larger scale.

There also is growing interest among state policymakers in the use of value-added analysis to measure teacher effectiveness and to assess the effectiveness of teacher education programs, alternative routes, and the impact of teacher licensing tests and advanced certification. The publicity given to the studies in Tennessee has led other states to explore the possibilities of using this methodology to inform policymakers and guide state decisions. This draws attention to the need for the development of better databases in order to support this kind of analysis.

The development of statewide data systems linking student and teacher data should lead to studies that will fill in some of these gaps. But even this development begs the larger question of whether policymakers will use the results of these studies to guide their decisions. At present, policymakers appear to be ignoring the research evidence that is available. Yes, they are supporting teacher induction programs and to a lesser degree professional development for teachers. However, the devil is in the details. Requiring induction programs is a good idea, but the potential gains will not be realized if the specific qualities related to their effectiveness are ignored. And this requires consistent state support and investment in strong systems of induction. Simply adopting broad regulations requiring districts to provide mentors is unlikely to produce the benefits associated with the multifaceted, well-designed programs adopted in Connecticut or California or piloted in Texas and New Jersey. More professional development also is a good idea, but not if state recertification requirements are used to encourage teachers to accumulate "hours" and partici- pate in many fragmented, low-quality activities, or if annual accountability cycles drive schools to seek quick fixes.

Moreover, it is clear that providing data is not sufficient; policymakers also must understand and value evidence. There are some indications that the federally led efforts to improve the quality of evidence about the effects of educational programs and to insist that it be used by school system officials are paying some dividends. Publishers say that school-district leaders are beginning to ask for evidence of effectiveness when they purchase textbooks and curricular programs. As a consequence, publishers are investing in field trials for their primary products to provide such evidence. Perhaps state policymakers will follow suit.

\section{Summing Up: The Evidence, the Profession, and Policy}

Do we have the kind of research evidence we need to guide the development of policy in these six critical domains that affect the quality of teachers and teaching? The answers are mixed. We have compelling evidence about the effects of induction, and a growing evidence base about the qualities of effective alternative route-programs. We lack compelling evidence about teacher licensing, teacher education, and teacher compensation reforms, although the evidence about some aspects of teacher education (the impact of math teachers taking math and math methods courses, for example) is useful.

The development of statewide data systems linking student and teacher data should lead to studies that will fill in some of these gaps. But even this development begs the larger question of whether policymakers will use the results of these studies to guide their decisions. At present, policymakers appear to be ignoring the research evidence that is available. Yes, they are supporting teacher induction programs and to a lesser degree professional development for teachers. However, the devil is in the details. Requiring induction programs is a good idea, but the potential gains will not be realized if the specific qualities related to their effectiveness are ignored. And this requires consistent state support and 
investment in strong systems of induction. Simply adopting broad regulations requiring districts to provide mentors is unlikely to produce the benefits associated with the multifaceted, well-designed programs adopted in Connecticut or California or piloted in Texas and New Jersey. More professional development also is a good idea, but not if state recertification requirements are used to encourage teachers to accumulate "hours" and participate in many fragmented, low-quality activities, or if annual accountability cycles drive schools to seek quick fixes.

Some of the policy debates are hard to resolve with appeals to evidence. Those who seek higher licensing standards and stronger teacher preparation programs hold different visions of good teaching than the deregulation, free-market crowd. These issues cannot be fully mediated through better empirical research.

Clearly there are many important questions here that can be addressed through better designed research. To name a few in the domain of teacher education: Would raising entrance requirements for teacher education programs or conducting more selective screening ensure that graduates would be more likely to take jobs as teachers and be more effective? Do candidates have adequate subject matter preparation? What do institutions of higher education do to ensure this? What could they do? Why do so many who enter pre-service programs choose not to become teachers? Similar questions arise in each of the six domains. The more pressing question is how we convince policymakers to pay attention to findings when they are compelling. Yes, some do already, and others do it selectively when it suits their agendas and their constituents. But we need only look at the case of teacher induction to see how whimsical policymakers can be about attending to research findings.

We also need to think harder about how research findings are disseminated and to whom they are disseminated. It seems clear that policymakers pay attention to public and institutional pressures for action. Perhaps the policy research community needs to become more media-wise, and to learn from the social marketing efforts that affected public health, conservation, driving habits, and other areas of social behavior and social policy. We have convinced the public of the value of the comprehensive high school, class size reduction, Advanced Placement coursework, and other education policies. And when we convinced them, they demanded action by policymakers. The policy research community should see its audience as broader than those in government; it should also be speaking to citizens and to community groups who can influence what actions policy makers will take.

\section{About the Author}

Thomas B. Corcoran is a co-director of the Consortium for Policy Research in Education (CPRE). Prior to joining CPRE, he served as policy adviser for education for New Jersey Gov. Jim Florio, director of school improvement for Research for Better Schools, and director of evaluation and chief of staff of the New Jersey Department of Education. He has served as a consultant to urban school districts and national foundations on issues of improving quality and equity. Mr. Corcoran's research interests focus on ways of improving the use of research findings and clinical expertise to inform policy and practice, the effectiveness of different approaches to professional development, the impact of changes in work environments on the productivity of teachers and students, the efficacy of state teacher policies, and the evaluation of high school reforms. He is a member of the National Research Council's Science Learning Study, the International Baccalaureate Organization's Research Committee, the New Jersey Quality Teaching and Learning Commission, the advisory committee for the Mathematics and Science Partnerships Knowledge Management Project supported by the National Science Foundation,, and the Merck Institute for Science Education Critical Friends Group. 


\section{References}

Allen, M. B. (2003). Eight questions on teacher preparation: What does the research say? Denver, CO: Education Commission of the States.

American Federation of Teachers. (1999). Principles for professional development: AFT's guidelines for creating professional development. Washington, DC: Author.

Azordegan, J., Byrnett, P., Campbell, K., Greenman, J., \& Coulter, T. (2005) Diversifying teacher compensation (ECS Issue Paper). Denver, CO: Education Commission of the States.

Berry, B. (2005). Taking action to improve teaching quality: Addressing shortcomings in the Teaching Commission report. Chapel Hill, NC: The Center for Teacher Quality.

Carnegie Corporation of New York. (2001). Teachers for a New Era: A national initiative to improve the quality of teaching. New York: Author.

Cochran-Smith, M., \& Fries, M. K. (2001). Sticks, stones, and ideology: The discourse of reform in teacher education. Educational Researcher 30 (8), 3-15.

Cochran-Smith, M., \& Zeichner, K. M. (Eds.). (2005). Studying teacher education: The report of the AERA Panel on Research and Teacher Education. Mahwah NJ: Lawrence Erlbaum Associates, Inc.

Cohen, D. K., \& Hill, H. C. (1998). Instructional policy and classroom performance: The mathematics reform in California (CPRE Research Report No. RR-39). Philadelphia: University of Pennsylvania, Consortium for Policy Research in Education.

Cohen, D. K., Fuhrman, S.H., \& Mosher, F. (Eds.) (in press). The State of Education Policy Research. Mahwah, NJ: Lawrence Erlbaum Associates, Inc.

Corcoran, T. B. (1995). Helping teachers teach well: Transforming professional development (CPRE Policy Brief No. RB-16). New Brunswick, NJ: Rutgers University, Consortium for Policy Research in Education.

Corcoran, T., Goertz, M., Robinson, M., \& Riordan, J. (2006). Teachers for a New Era: Final report. Philadelphia: University of Pennsylvania, Consortium for Policy Research in Education.
Corcoran, T., McVay, S., \& Riordan, K. (2003). Getting it right: The MISE approach to professional development (CPRE Research Report No. RR-055). Philadelphia: University of Pennsylvania, Consortium for Policy Research in Education..

Corcoran, T. B., Walker, L. J., \& White, J. L. (1988). Working in urban schools. Washington, DC: Institute for Educational Leadership.

Darling-Hammond, L. (2000). Reforming teacher preparation and licensing: Debating the evidence. Teachers College Record 102(1), 28-56.

Elmore, R. F. (2002). Bridging the gap between standards and achievement: The imperative for professional development in education. Washington, DC: Albert Shanker Institute.

Elmore, R. F., \& Burney, D. (1997). Investing in teacher learning: Staff development and instructional improvement in community school district \#2, New York City. New York: Columbia University, Teachers College, National Commission on Teaching and America's Future; Philadelphia: University of Pennsylvania, Consortium for Policy Research in Education.

EPPI-Centre. (2004). The impact of newly qualified teachers (NQT) induction programmes on the enhancement of teacher expertise, professional development, job satisfaction or retention rates: A systematic review of research literature on induction. London, England: University of London, Institute of Education, Author.

Evertson, C., Hawley, W., \& Zlotnik, M. (1985). Making a difference in educational quality through teacher education. Journal of Teacher Education 36(3), 2-12.

Feistritzer, C.E. (2006). Alternative teacher certification: A state-by-state analysis, 2006. Washington, DC: National Center for Education Information.

Fenstermacher, G.D. (2002). A commentary on research that serves teacher education. Journal of Teacher Education, 53(3), pp. 242247.

Ferguson, R. (1991). Paying for public education: New evidence on how and why money matters. Cambridge, MA: Harvard University, John F. Kennedy School of Government. 
Firestone, W. A. (1994). Redesigning teacher salary systems for educational reform. American Educational Research Journal, 31(3), 549-574.

Freiberg, H. J., \& Knight, S. L. (1991). Career ladder programs as incentives for teachers. In S. C. Conley \& B. S. Cooper (Eds.), The school as a work environment: Implications for reform (pp. 204-235). Boston: Allyn \& Bacon.

Garet, M. S., Birman, B. F., Porter, A. C, Desimone, L., Herman, R., \& Yoon, K. S. (1999). Designing effective professional development: Lessons from the Eisenhower Program. Washington, DC: American Institutes for Research.

Goldhaber, D. (2006). Everybody's doing it, but what does teacher testing tell us about teacher effectiveness? Seattle, WA: University of Washington, Center on Reinventing Public Education.

Goldhaber, D., \& Brewer, D. J. (2000). Does teacher certification matter? High school teacher certification status and student achievement. Educational Evaluation and Policy Analysis, 22(2), 129-145.

Hatry, H. P., Greiner, J. M., \& Ashford, B. G. (1994). Issues and case studies in teacher incentive plans. Washington, DC: Urban Institute.

Hawley, W., \& Valli, L. (1999). The essentials of effective professional development: A new consensus. In L. Darling-Hammond \& G. Sykes (Eds.), Teaching as the learning profession: Handbook of policy and practice (pp. 127-150). San Francisco: Jossey-Bass.

Heneman, H. G. III, \& Milanowski, A. (1999). Teacher attitudes about teacher bonuses under school-based performance award programs. Journal of Personnel Evaluation in Education, 12(4), 327-342.

Ingersoll, R., \& Kralik, J. (2004). The impact of mentoring on teacher retention: What the research says. Denver, CO: Education Commission of the States.

Ingersoll, R. M., \& Smith, T. M. (2004). Do teacher induction and mentoring matter? NASSP Bulletin, 88(638), 28-40.
Kelley, C., Heneman, H.G. III, \& Milanowski, A. (2000). School-based performance award programs, teacher motivation, and school performance: Findings from a study of three programs. Philadelphia: University of Pennsylvania, Consortium for Policy Research in Education.

Kennedy, M. M. (1999). Form and substance in mathematics and science professional development (NISE Brief Vol. 3, No. 2). Madison, WI: University of Wisconsin-Madison, National Institute for Science Education.

Knapp, M. S., McCaffrey, T., \& Swanson, J. (2003). District support for professional learning: What research says and has yet to establish. Paper presented at the annual meeting of the American Educational Research Association, Chicago.

Milanowski, A. T. (1999). Measurement error or meaningful change? The consistency of school achievement in two school-based performance award programs. Journal of Personnel Evaluation in Education, 12(4), 343-363.

- . (2003). The varieties of knowledge and skill-based pay design: A comparison of seven new pay systems for $\mathrm{K}-12$ teachers. Education Policy Analysis Archives, 11(4).

Milanowski, A.T., Kimball, S.M., \& Odden, A. (2005). Teacher accountability measures and links to learning. In L. Stiefel \& A.E. Schwartz \& R. Rubenstein \& J. Zabel (Eds.), Measuring School Performance and Efficiency: Implications for Practice and Research (Yearbook of the American Education Finance Association) (pp. 137-161).

Miles, K. H., Odden, A., Fermanich, M., \& Archibald, S. (2004). Inside the black box of school district spending on professional development: Lessons from five urban districts. Journal of Education Finance, 30(1), 1-26.

Miller, B., Lord, B., \& Dorney, J. (1994). Staff development for teachers. Newton, MA: Educational Development Center.

Murnane, R. J., \& Cohen, D. K. (1986). Merit pay and the evaluation problem. Harvard Educational Review, 56(1), 1-17.

National Commission on Teaching and America's Future (1996). What matters most: Teaching for America's future. New York: Author. 


\section{Policy Briefs}

(1997). Doing what matters most: Investing in quality teaching. New York: Author.

National Staff Development Council. (2001). Standards for staff development: Revised. Oxford, OH: Author.

Oakes, J., Franke, M.L., Quartz, K.H., \& Rogers, J. (2002). Research for high quality teaching: Defining it, developing it, assessing it. Journal of Teacher Education, 53(3), 228234.

Reichardt, R., \& Van Buhler, R. (2003). Recruiting and retaining teachers with alternative pay. Aurora, CO: Mid-Continent Research for Education and Learning.

Sanders, W. L., \& Horn, S. P. (1998). Research findings from the Tennessee valueadded assessment system (TVAAS) database: Implications for educational evaluation and research. Journal of Personnel Evaluation in Education, 12(3), 247-256.

Sanders, W. L., \& Rivers, J.C. (1996). Сumulative and residual effects of teachers on student achievement. Knoxville, TN: University of Tennessee Value-Added Research and Assessment Center.

Schlechty, P.C. (1989). Career Ladders: A good idea gone awry. In T.J. Sergiovanni \& J.H. Moore (Eds.), Schooling for tomorrow: Directing Reforms to issues that count (pp. 356-376). Boston: Allyn \& Bacon.

Solmon, L. C., \& Podgursky, M. (2000). The pros and cons of performance-based compensation. Santa Monica, CA: Milken Family Foundation.

SRI International. (2004). Review of research on the impact of beginning teacher induction on teacher quality and retention. Menlo Park, CA: Author.

Supovitz, J. A., Mayer, D., \& Kahle, J. B. (2000). The longitudinal impact of inquirybased professional development on teaching practice. Educational Policy, 14(3), 331-356.

Teaching Commission. (2004). Teaching at risk: A call to action. New York: Author.

(2006). Teaching at risk: Progress and potholes. Final report. New York: Author.
Torres, J., Santos, J., Peck, N. L., \& Cortes, L. (2004). Minority teacher recruitment, development, and retention. Providence, RI: Brown University, Education Alliance.

U.S. Department of Education. (2002). Meeting the highly qualified teacher challenge. Washington, DC: Author, Office of Postsecondary Education, Office of Policy Planning and Innovation. Retrieved February 23, 2007, from http://www.ed.gov/offices/OPE/News/ teacherprep/AnnualReport.pdf.

U.S. Department of Education. (2005). The secretary's fourth annual report on teacher quality: A highly qualified teacher in every classroom. Washington, DC: Author, Office of Postsecondary Education. Retrieved February 23, 2007, from http://www.title2.org/TitleIIReport05.pdf.

Weiss, E. M., \& Weiss, S. G. (1999). Beginning teacher induction. Washington, DC: ERIC Clearinghouse on Teaching and Teacher Education.

Wilson, S. M., \& Berne, J. (1999). Teacher learning and the acquisition of professional knowledge: An examination of research on contemporary professional development. In A. Iran-Nejad \& P. D. Pearson (Eds.), Review of Research in Education (pp. 173-209). Washington, DC: American Educational Research Association.

Wilson, S., Floden, R., \& Ferrini-Mundy, J. (2001). Teacher preparation research: Current knowledge, gaps, and recommendations. Seattle, WA: Center for the Study of Teaching and Policy.

Wyckoff, J., Boyd, D. J., Grossman, P., Lankford, H., Loeb, S., \& Michelli, N. M., (2006). Complex by Design. Investigating pathways into teaching in NY city schools. Journal of teacher education, 57(2), 155-166. 


\section{Recent CPRE Publications}

The following is a list of selected publications reporting on the issue of recruiting and retaining qualified teachers-a key factor for improving student achievement and a fundamental problem facing schools in the United States. CPRE researchers examine organizational factors and conditions in schools leading to school staffing problems - such as teacher job dissatisfaction and compensation issues.

Visit www.cpre.org for more information on any of the following products published by the Consortium for Policy Research in Education. To obtain journal articles, please contact the organization and/or publisher directly.

Borman, G., \& Kimball, S. (2005). Teacher quality and educational quality: Do teachers with higher standards-based evaluation ratings close student achievement gaps? The Elementary School Journal, 106(1), 3-20.

Gallagher, A.H. (2004). Vaughn Elementary's innovative teacher evaluation system: Are teacher evaluation scores related to growth in student achievement? Peabody Journal of Education, 79(4), 79-107.

Heneman, H.G. III, \& Milanowski, A. (2004). Alignment of human resource practices and teacher performance competency. Peabody Journal of Education, 79(4), 108-125.

Hill, H., Rowan, B., \& Ball, D.L. (2005). Effects of teachers' mathematical knowledge for teaching on student achievement. American Educational Research Journal, 42(2), 371-406.

Ingersoll, R. (2003). Is there really a teacher shortage? Co-Published with the Center for the Study of Teaching and Policy. Philadelphia: The Consortium for Policy Research in Education.

Ingersoll, R. (2003). Out-of-field teaching and the limits of teacher policy. Co-Published with the Center for the Study of Teaching and Policy. Philadelphia: The Consortium for Policy Research in Education.

Ingersoll, R. (2003). Who controls teachers' work? Power and accountability in America's schools. Cambridge, MA: Harvard University Press.
Ingersoll, R., \& Kralik, J. (2004). The impact of mentoring on teacher retention: What the research says. Denver: Education Commission of the States

Kimball, S., Heneman, H.G. III, \& Kellor, E. (2003). Pensions for teachers: Possible changes and implications. (CPRE UW- Working Paper Series, No. TC-03-09). Philadelphia: Consortium for Policy Research in Education.

Milanowski, A., \& Heneman, H.G. III (2003). Continuing assessment of teacher reactions to a standards-based teacher evaluation system. Journal of Personnel Evaluation in Education, 17(2), 173-195.

Odden, A. (2003). An early assessment of comprehensive teacher compensation change plans. In D. Monk and M. Plecki (Eds.), School finance and teacher quality: Exploring the connections. 2003 Annual Yearbook of the American Education Finance Association (pp. 209228). Philadelphia: Eye on Education.

Odden, A., Kelley, C., Heneman, H.G. III, \& Milanowski, A. (2001). Enhancing teacher quality through knowledge and skills-based pay. (CPRE Research Brief No. RB-34). Philadelphia: The Consortium for Policy Research in Education. 


\section{Nondiscrimination Statement}

The University of Pennsylvania values diversity and seeks talented students, faculty, and staff from diverse backgrounds. The University of Pennsylvania does not discriminate on the basis of race, sex, sexual orientation, religion, color, national or ethnic origin, age, disability, or status as a Vietnam era veteran or disabled veteran in the administration of educational policies, programs, or activities; admissions policies, scholarships, or loan awards; and athletic or University-administered programs or employment. Questions or complaints regarding this policy should be directed to Executive Director, Office of Affirmative Action, 1133 Blockley Hall, Philadelphia, PA 19104-6021 or 215-898-6993 (Voice) or 215-898-7803 (TDD).

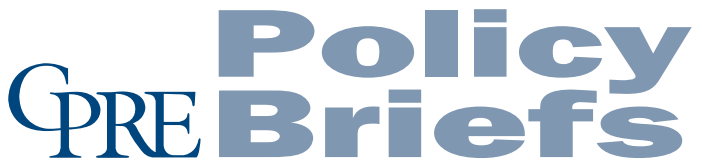

Graduate School of Education University of Pennsylvania 3440 Market Street, Suite 560

Philadelphia, PA 19104-3325

\section{About CPRE}

The Consortium for Policy Research in Education (CPRE) studies alternative approaches to education reform in order to determine how state and local policies can promote student learning. Currently, CPRE's work is focusing on accountability policies, efforts to build capacity at various levels within the education system, methods of allocating resources and compensating teachers, instructional improvement, finance, and student and teacher standards. The results of this research are shared with policymakers, educators, and other interested individuals and organizations in order to promote improvements in policy design and implementation.

CPRE unites seven of the nation's leading research institutions to improve elementary and secondary education through research on policy, finance, school reform, and school governance. Members of CPRE are the University of Pennsylvania, Teachers College Columbia University, Harvard University, Stanford University, the University of Michigan, Northwestern University, and the University of WisconsinMadison.

CPRE Policy Briefs are published by CPRE. To learn more about CPRE research or publications, please call 215-573-0700 or access CPRE publications at www.cpre.org; www.wcer.

wisc.edu/cpre/; or www.sii.soe.umich.edu.
NON PROFIT

U.S. POSTAGE

PAID

PERMIT NO. 2563

PHILADELPHIA, PA 